\title{
EXPERIMENTAL MARKETING IN HOTEL OPERATIONS
}

\author{
Luan VARDARI $I^{1}$, Dena ARAPI
}

Geliş: 03.11.2017 Kabul: 14.12.2017

DOI: 10.29029/busbed.348950

\section{Abstract}

Throughout 21 'st century, marketing managers, brand managers, marketing academics have adopted the classic marketing discipline. This approach has defined consumers as rational decision-making, benefit-focused individuals. Today's consumer, however, has become more emotional decision-making individuals than rational decision-making individuals. Consumers are not only concerned with the functional value of the product or service they provide to them, but they also deal with the pleasant feelings they have created and the additional value they create in their memory. In modern marketing, businesses are trying to establish this additional value by creating "experience" for their customers.

Due to the humanity-based nature of the tourism industry, consumer behavior has an important place in tourism marketing. The analysis of consumer behavior in tourism is only possible with the meaning of the product or service carried by the tourists and by determining the factors that are effective in making the holiday purchase decision. Along with the change of economic presentation, the process from consumer to service, from service towards experiment, has revealed the concept of experiential marketing.

Tourism products and services, personalization and experience to have the quality of experience in terms of experience in the economy is are ahead in the race. This will provide an important advantage in creating customer loyalty if it is guided and managed by hotel and accommodation operators correctly.

Keywords: Experiential marketing, hotel management, Business, Kosovo, Turkey

1 Lecturer Phd, Univeristy of Prizren “UKSHIN HOTI”, luan.vardari@uni-prizren.com

2 MSc., University of Prishtina, denaarapi@hotmail.com 


\section{OTEL IŞLETMELERINDE DENEYIMSEL PAZARLAMA}

\section{$\ddot{O} z$}

21. yüzylldan bu yana, pazarlama müdürleri, marka sorumlularl ve pazarlama alanindaki akademisyenler klasik pazarlama disiplinini benimsemiştir. Her ne kadar günümüz tüketicileri mantıklarından ziyade duygularlyla karar veren bireyler olsa da bu yaklaşım tüketicileri mantıklı kararlar veren kar odaklı bireyler olarak tanımlamıştır. Tüketiciler kendilerine sunulan hizmet ve ürünlerin klymetlerini takdir etmekle beraber bunların meydana getirdiği haz ve klymeti de hatıralarında saklarlar. Modern pazarlamada iş adamları bu ilave değeri müşterilerine deneyim yaşatarak Inşa etmeye çalı̧̧maktadırlar.

Turizm sanayiinin İnsan odaklı doğasından ötürü tüketici davranışı turizm pazarlamasında önemli bir yere sahiptir. Turizmde tüketici davranışının incelenmesi sadece turistlere sunulan ürün ve hizmet gayesi ile ve tatil kararını vermede etkili olan faktörleri tespit etmekle mümkündür. Ekonomik sunumların değişmesiyle birlikte tüketiciden hizmete ve hizmetten deneyime dönüşen süreç deneyimsel pazarlama kavramını ortaya çıkarmıştır.

Turizm ürün ve hizmetleri, kişiselleştirme ve ekonomide iyi bir tecrübe edinmek bu yarışta en önemli unsurlardan biridir. Ĕger tüm bunlar otel ve konaklama işletmecileri tarafindan doğru bir şekilde yönlendirilip ve idare edilirse müşteri güvenini oluşturmada önemli bir avantaj sağlayacaktır.

Anahtar Kelimeler: Deneyimsel Pazarlama, Otel Yönetimi, İşletme, Kosova, Türkiye.

\section{Literature Review}

Thommson (2012), in this study concludes that experimental marketing can boost purchasing goals. More specifically, marketing experience can boost positive purchasing goals through emotional values and value functions mainly through perceptions of thought. For example, in a Marriott resident company, further research may explore other experimental marketing, including experimental offerings at resorts or physical brand premises such as bus travel to Marriott Hawaii (Thomson, 2010: 67).

Khan and Others (2015) in their study have conducted empirical analyses on "Customer Service Experience in Hotel Operations". The result prevailed a significant impact on customer satisfaction. Customer satisfaction influences both brand loyalty and word of mouth, and the indirect effect of customer satisfaction in word of mouth through brand loyalty is very strong. In general, this study extends the applicability of client experience to hotel operations, which makes marketers 
think about different contact points during customer interaction with hotel brand (Khan and Others, 2015: 267).

Hossein and others stated the main objective to investigate the impact of customer service on the quality of experience and brand loyalty in Iran and to propose a model for the hotel industry in Iran. Therefore, the findings would contribute on improving the management of hotels and tourism industry in Iran. The study received data from 302 international and local clients at four and five star hotels in five major cities in Iran. This has significantly contributed to Iranian tourism market in efforts to improve the efficiency of hotel customers and loyalty to Iran. The effect of the extent of service performance in brand loyalty has not been investigated in the hospitality industry in Iran. From a practical or managerial perspective, this kind of study would aid hotel managers to give serious thoughts to addressing and developing marketing strategies (Hossein and others, 2015: 201)

\section{What is Experiential Marketing?}

Experiential Marketing; "Experimental Marketing" is based on the use of customer experience in marketing. Marketers have been talking about focusing on customers for years. However, when we look at existing marketing concepts, we see that most of them are product and consumption oriented. Prior to the information technologies, brand and communication revolutions, traditional marketing approaches of an industrial age do not correspond to nowadays conditions. "Experience marketing focuses on understanding customers' experiences and creating new experiences (Schmit, 1999: 14-16).

The basis of creating experience is undoubtedly customer satisfaction. Customer satisfaction is the fulfillment of customer expectations. However, creating customer satisfaction is not enough to maintain customers. In this sense, it should be possible to offer a different value to customers beyond customer satisfaction, which is a guide to creating this difference in the needs of experiential marketing enterprises (Songur et al., 2012, 439)

\section{Definition and Types of Experimental Marketing}

Bernd Schmitt is one of the first to bring up the concept of experiential marketing. Schmitt says that traditional marketing is acting according to the assumption that the consumer considers rational decision makers, that people are tangibly aware of the benefits and features of the products they will be choosing, and that they make a price comparison. According to B. Schmitt, who is considered to be pioneer of an approach, in explanations on experiential marketing states that the experience is the result of what is experienced, exposed and encountered and aims to create experiences for marketing consumers (Odabaş1, 2004: 12-13). 
Lewis and Chambers express the experience or more specifically, the consumption experience: the sum of the goods and services purchased for the customer combined with the environment. Experience is an important opportunity for hospitality and tourism sector. (Erin and Kenny, 2008: 387).

Schmitt suggests that companies offer experience because customers are so important to the success of the company. Creating an unforgettable experience is important for retaining old customers and attracting new ones. Compared to traditional marketing, experiential marketing focuses more on the customer during the experience creation process, including pre-purchase, current reality, and post-purchase (Schmit, 1999: 14-16).

For the past 30 years, marketing and consumer research have been reviewing the literature, consumer experience, and junk consumption. The main reason for the emergence of the experience that has begun to be shaped by the notion of preliminary experience is that the traditional benefits and benefits of marketing are no longer sufficient to meet the needs of consumers. The changes in consumer demand, increased competition in the service sector, and at the same time, the communication and enjoyment of interactions in many places has led to an understanding of the development experience, due to the presence of information technology, the superiority of the brand, the increase in consumer wealth and knowledge (Özgören, 2013: 2).

These developments have led to the concept of experience taking place in nowadays marketing literature and attracting the attention of many academicians and different descriptions related to experience have been made. Experience does not have a single definition of the concept. However, if you want to summarize the experience; (Kazançoğlu ve Miscellaneous, 2011: 231), which is different from the product and service that affect the consumer emotional, physical, intellectual and spiritually, which emerges at the moment of production and consumption based on the participation of the consumer.

Pine and Gillmore (1998), creators of the concept of experience; experience, customer involvement and environmental involvement. Customer participation; refers to the active or passive participation of customers in the experience that enterprises offer to their customers. In other words, active participation means that the client is involved in the experience of a verb operator, whereas passive participation is that the client participates in the experience of the operator. If we are going to give an example from an entertainment park like Walt- Disney; A demonstration in Walt- Disney is the only passive participation of the customer, and this demonstration represents active participation in an interactive way (singing, etc.) (Günay, 2008: 186). 
Environmental relations mean a combination of experience and customer. Accordingly, the customer has either a weak or strong relationship with the experience. The customer who watches the game on the field side of the football game is in a stronger relationship with the experience, while the partner who watches the game in a more remote place is in a weaker relation with the experience. These two dimensions of experience constitute four different types of experience. These are the experiences of entertainment, education, aesthetics and escape (Kabadayi et al., 2014: 207):

- Entertainment experience; poor environmental relations and passive customer participation. This is an example of watching a play in the background.

- Educational experience, poor environmental relations, and active customer participation come into play. An example of this is the student taking the tennis course.

- Aesthetic experience arises from strong environmental relations and passive customer participation. Participation in an art exhibition can be given as an example.

- The escape experience, on the other hand, as evidenced by strong environmental involvement and active customer participation. This can be exemplified by a customer skiing at a mountain hotel (Sundbo and Darmer, 2008).

Experiential marketing is a holistic consumption experience that consists of stimuli designed by the customer before and after the purchase event. Schmitt has argued that experiential marketing can have five different basic experiences for customers. These; sensory experience, sense, feel cognitive experience, physical experience, and relate the experience (Berry and others, 2006).

Sensory experience; sight, hearing, touching, tasting and smelling. It is used by enterprises to create differentiation in products/services. Businesses can make this experience by adding value to the product provided they change the aesthetic characteristics of the product. The basic principle of sensory experience is cognitive consistency and sensory diversity. Thanks to the cognitive coherence and sensory diversity that these experiences provide, they appeal to the five senses and give the customers pleasure and excitement in an aesthetic sense (Kabaday1 et al., 2014: 209).

Emotional experience; It is the creation of positive emotional experiences and strong emotions about the brand in the customers. As per to emotional experience to be managed, marketers need to analyze how stimulants will create emotions in the customer, and then develop marketing mix elements. In today's marketplace, consumers do not only take the products because of their functional benefits or 
product characteristics, but they also take into consideration their emotional experiences. For this reason, businesses should empathize with their customers and meet their emotional experience needs. (Yu and KO, 2012: 9).

Through cognitive experience, it is aimed to create problem-solving experiences for the customers. With messages sent to customers, businesses aim to provide positive thinking about customers' brands and try to differentiate their positioning from their competitors. In this experience, it is aimed to send messages to the customers by surprise and to take them to action. It is usually used in new technology products. Microsoft's campaign "Where do you want to go today?" Aims to create experiences for customers by suggesting them (Günay, 2008: 187).

Through physical experience, businesses focus on their customers' behavioral experiences with the product. With this approach, businesses aim to create an experience by examining the changes in their customers' lifestyles, the way they do things, and their behavior. In other words, physical experiences are behavioral experiences that, beyond sensory, emotional, and cognitive experiences, interact with customers, appeal to their lifestyles, and act on them. Businesses are aiming to create a physical experience using famous people in their campaigns. Nike's "Just Do It" campaign has a classic example of doing business (Kabadayi et al., 2014: 209).

Social life experience; emotional experience, cognitive experience, and physical experience in a holistic way. It tries to establish a link between the brand or product and consumers. The focus is on the ideal self, rather than the personal feelings of the customers, and trying to create a sense of belonging to a group or brand. Brand associations, for example. Harley Davidson, for example, has become a lifestyle rather than a means of transport for motorists (Yu and KO, 2012: 11).

It aims to provide pleasant and memorable experiences to consumers, businesses using sensory experience, emotional experience, cognitive experience, physical experience and social experience in the right way.

\section{Features of Experiential Marketing}

Traditional marketing is an approach that focuses on product features and benefits, with product category and competition being limited, assessed by analytical, quantitative and qualitative methods, addressing rational decision makers. The focus of the experiential marketing approach is on customer experience (Babacan and Onat, 2002: 15).

Mental, emotional, cognitive, behavioral, and relational values experiences, taking the place of the functional values that the product/service provides. In this marketing approach, marketers; shampoo, soap, perfume, lotion instead of treating 
products according to their properties or functions; as part of their "experience of preparation", and all the marketing processes from their advertising to their packaging are organized by taking into account the consumption experience (Uighur and Dogan, 2013: 35).

Consumption is a holistic experience in this approach. Compared to traditional marketing understanding, competition is based on brand or product. Competition is addressed at the macro level in this approach. This approach sees consumers not only as rational decision makers but also as emotional decision makers. In order to evaluate marketing output, not only analytical, quantitative and qualitative research methods like traditional marketing approach are preferred, along with experiential design methods (Schmit, 1999: 14-16).

Experiential marketing is an approach that addresses rational and emotional customers, eclectic methods, consumer consumption as a holistic experience, and focuses on customer experiences. When the development of marketing from past to present is observed; The commodity, which is important in the production-oriented management understanding, has left its place in the experience which is important in the customer-oriented management understanding. According to the concept of "Experience Economy" put forward by Pine and Gillmore (1998), the notion of experience is the fourth economic offering directed at consumers by commodities differently from commodities, products, and services. In other words, the experience is as real as offering products/services to consumer, and it offers the opportunity to make it easier to sell, to enrich the products/services with experience, especially for service businesses. They argued that these economic presentations are the source of future profitability and differentiation from their competitors for businesses.

\section{The Importance of Experiential Marketing}

Businesses need differentiated products and services in order to be able to manage their relations with their customers for a long time and to develop common relationships. In this context, enterprises have sought to make a difference. Businesses are trying to provide pleasant experiences that can be kept in mind thus to make a difference to their customers. In this context, experiential marketing is an important guide to bring customer experience to businesses (Günay, 2008: 64).

Experiential Marketing manages all the dots in the whole, are not for the customers only. It ensures that the brand experience promised is compatible. The product manages itself to serve the described experiment (www.ulviyaman.com), advertising, the internet, the activities that the brand carries out, the identity of the brand, the cooperation with other brands, the buildings used by the brand and the people who are the most important, namely the sellers and service personnel. It is natural that someone who has experience with the product or service is willing 
to use it. There is a research with its evidence of this situation. For example, 74\% of businesses in the US say that sales of experiential marketing are increasing. Although this ratio is less in Turkey, the most important effect of experiential marketing is reflected in sales. Your experience is a great asset in terms of customer satisfaction. The customer, who is happy to return home, wants the next product or service (Schmit, 1999: 14-16).

One of the most important benefits of experiential marketing is the feeling of loyalty instilled in the customer. As a result of living experience, it becomes an act of feeling the feeling of loyalty sprouting under the consciousness, the need to get product or service. The loyalty process for the customer who has thousands of products or services every day is not very long. At this point, brands will make experiential marketing a premium service rather than a permanent service (www. pazarlamasyon.com).

Nowadays it is well accepted that customers have a unique and unforgettable experience for businesses. Customers do not buy a product or service just because of the benefits they provide, but they are also interested in the nice experiences that they have left in their memory. In other words, as Baudrillard points out, "modern consumers do not consume products but rather consume the meanings of products" and the meaning of "products" in this explanation can be explained as experiences of consumers in products (Özgören, 2013: 7).

Gillmore and Pine (2002), architects of experience marketing, have made the following statement regarding the experience; "Marketing makes the sales aim unnecessary, the experience is to make marketing unnecessary". As can be understood from this explanation, the notion of experience is shaping today's marketing concept and is considered as the main factor that businesses should pay attention to in order to gain competitive advantage (Kabaday1 and others, 2014: 2).

\section{Use of Experiential Marketing in the Tourism Sector and Hotel Business}

Due to the humanity-based nature of the tourism industry, consumer behavior has an important place in tourism marketing. The analysis of consumer behavior in tourism is only possible with the meaning of the product or service carried by the tourists and by determining the factors that are effective in making the holiday purchase decision. Along with the change of economic presentation, the process from consumer to service, from service towards experiment, has revealed the concept of experiential marketing.

Experimental marketing, which aims to make products and services unique to the consumer by creating a customer experience, is an important tool for creating customer satisfaction and loyalty. Tourism products and services, personalization and experience to have the quality of experience in terms of experience in the economy is 
ahead in the race. This will provide a significant advantage in creating customer loyalty if it is guided and managed correctly by tourism operators (Saltık, 2011:1).

Wang supports assertions that there are still ambiguities about the dimensions and content of the tourist experience. Because there is a sharp contrast between daily experiences and tourist experiences. While touristic experiences are understood as peak experiences that derive from the charm, daily experiences like eating/drinking, accommodation, transportation are returned as supportive experiences. However, supportive experiences draw more attention because tourists are expecting quality service, quality food, and hospitality (Papatya et al., 2013: 89).

Charms that do not exist in everyday life make tourism product part of total consumption. The service sector adapted from Maslow's hierarchy has a hierarchy of experiential values, a dimension of 'efficiency and economics' in the base of physiological needs, a dimension of 'perfection' in the need of security, a dimension of social interaction and appreciation in the need of security and love, , escape, pleasure, activity, reference, economy "(Oral and Steel, 2013: 172).

In particular, the entertainment and escape dimension outcomes of the experiential value approach are the most important value drivers in the tourism sector, which will enhance the loyalty of the customers to the business. Tourists want to relax, feel happy and get away from the problems in a different environment when they are out of their leisure and vacation areas. The escape dimension, which is the dimension that has the most dominant effect on total vacation satisfaction, reveals the importance of touching the intellectual feelings of tourists. This dimension, which we call spirituality, has changed the nature of touristic products. As Sims and others pointed out, this dimension will ensure that experiences, businesses, and countries are remembered (Absolut, 2011: 39).

Hospitality enterprises should, therefore, provide an environment where they can satisfy these critical points of tourists who want to escape their problems, to forget their problems for a certain period of time, to desire mental renewal, to gain self-confidence and to discover their identity. According to Smith \& Wheeler, internal resources (human resources) are one of the most influential factors in research. Schmitt emphasizes that the interaction of occupants and customers can create a comprehensive experience environment and service strategy. In the first phase of the experience circles, managers should set out internal resources that recognize the importance of offering promises of experience, helping to meet expectations after identifying client expectations.

It turns out that businesses that want to transform their customers into loyal customers need to strengthen their human resources in particular. In this context, Smith \& Wheeler proposes to build human capital - for example, "Education of 
the employees in accordance with the brand promise and the expectations of the customers, rewarding the right behaviors, acting like customers in the occupations" - can be evaluated. Especially, accommodation operators working with foreign markets should employ high-quality foreign language knowledge and advanced communication skill (Kabaday1 et al., 2014: 7).

An esthetic and recreational factor are other critical value drivers that are significant in the research. Griffin \& Haylar, in his research on spaces, said that positive comments on architectural construction have increased the recall rate. Therefore, the emotional responses that customers give to the physical environment affect the behavior of customers (Uygur and Doğan, 2013: 159).

Service areas (hotels, restaurants, etc.) located within the aesthetic dimension provide the first impression in the service organization before the customer contacts the occupants. That is why these areas guide customers' ideas, expectations and attitudes. The aesthetic experiences provided to tourists enable the customer to find himself in a different environment, in different emotions, but also in the selection of destinations at the same time. Aesthetic elements are therefore seen to be important in attracting and attracting emotions in-person experiences (www. meetschmitt.com).

Design, décor, and ambiance to create affect customer perceptions and emotions (Wakefield \& Blodgett, 1999, Volo, 2009). So, it is very important to understand the emotional responses of people and to apply a design in the physical environment. The managers of the hospitality management must renew their inhouse design and decorations by following the fashion trends of their experience in the direction of their target markets.

The design and decoration of the hotel should attract tourists for the duration of their stay and make a memorable impact after the holidays. Many examples of large-scale accommodation establishments opened in Antalya in recent years are examples of the presence of aesthetic dimensions in accommodation establishments, such as choosing different exterior design applications such as ships, airplanes, palaces, butterflies, using Ottoman motifs or more modernized decorations (Papatya et al., 2013: 92).

Especially the accommodation enterprises that will enter the sector with new investments in the sector should definitely not ignore the different and original exterior design, interior design and decoration suitable for the theme in order to be able to make difference at first and attract attention and be a preferred business afterward. However, there are three points to be considered when producing fantastic tourism projects. In this case, the tourism sector is one of the most important responsibilities of the damage to the environment and nature. Therefore, in the 
course of producing remarkable projects, the consistency of all steps needs to be tested for sustainability (Oral ve Çelik, 2013: 177).

The entertainment dimension of investments for the aesthetics and activity dimension in the accommodation enterprises should also be considered as triggers. The emotions that customers experience during their stay affect their satisfaction, their behaviors and purchasing decisions are at the center of emotion, consumption, and link specific behavioral responses to people, objects, and events. In this context, emotions have a direct impact on purchasing decisions by creating satisfaction or dissatisfaction with the product or service and influencing consumer behavior. In a study of the influence of experience-based content in hospitality businesses on customer attitudes and behaviors, behavior in the positive direction (Papatya et al. (2011a).

Slatten (2011) and others have concluded that perceptual processes of atmospheric dimensions have resulted in a sense of entertainment, and that customers have become an important factor of loyalty by creating positive emotions in their fun.

Pine \& Gilmore (1999) emphasizes that customers are ready to pay for their experience at the value on economic level. Zhang's (2008) criterion of aesthetics, escape, education and entertainment interacted positively, while the economic value criterion was an ineffective factor on customer behaviors in a survey of experiences in the effect of customer experience and customer behaviors in a limited number of service providers (Papatya et al. (2011b).

\section{Examples of Experiential Marketing in Hotel Businesses}

Service in the hotel business is undoubtedly the most important factor. Hotel establishments should give service innovation a boost to gain competitive advantage. In service, one should get rid of it and differentiate. Some of the service innovations in hotel business are as follows:

Point Hotel Barbaros in Istanbul is also a good example of innovation in service and marketing innovation with its different design and service approach. By offering "home comfort and office technology" together; developing a special service understanding for business meetings; has set itself apart from other hotels by establishing an infrastructure of information technologies that are in accordance with the needs (Elçi, 2010). The hotel, which is completely decorated with Istanbul theme, has 265 works of 26 artists. The hotel has a library of approximately 3,000 books in Istanbul, the oldest book of which dates back to 1633. At the same time, based on the purchase of the hotel to sleep, 'sweet dreams' officials who developed the concept, lullabies, have prepared a special mattress and pillow menus. In addition, the hotel is putting 101 books of quality sleep in the head of the beds. And a $\mathrm{CD}$ of the nations of the nations of the world is presented to guests who remain (Durna and Babur, 2011: 74). 
A nice example of the innovations made in architecture with interesting architecture is the SARAP Hotel in Spain. The hotel, which stands out with its indented protruding structure in red, silver and gold color, represents the packaging on the lid of a wine bottle. The architecture of the hotel, which attracts attention with its interesting structure, is Frank Gehry, who has an international reputation.

One of the innovations made in hotel architecture is airport hotels with airplane cabin rooms. Airplanes and hotels are the greatest complementary items of travel. The airport's Hotels, which offer great comfort to travelers due to missed flight times and delayed flights, have become popular in recent years. There are three types of booking options at Yotel, London Gatwick Airport (South Terminal), London Heathrow Airport (Terminal 4) and Amsterdam Schiphol Airport; Premium, standard and twin cabin (www.gezirezervovi.com).

In the Adam \& Eve Hotel rooms in Antalya Belek, each of the rooms, or even every jacuzzi, is positioned as a "light therapy" center by changing the lighting depending on the frequency of sound, while the customized lighting options vary from person to person (www.gezikolik.com).

The Peninsula Beverly Hills offers guests a distinctive experience by offering private hologram cushions and the personalized room smells to guests in their room. The Suu Türkbükü Bodrum, which brings an innovative understanding to the hotel's bathrooms, offers its guests a different experience with its concept of excellence and naturalness being held on the front. In addition to Jacuzzi, Xantos Francesco Corleone cosmetics, special scales showing the fat percentage, special water menus, plasma televisions in the rooms, as well as plasma televisions in the bathrooms, make guests feel special.

Reflecting its innovative style with different designs and details, Tuti Restaurant in The Marmara Antalya collects guests' liking. There are different activity columns (climbing, art, spice, internet, library, graphite etc) in the restaurant. For example, the art column contains pictures of different artists during different periods. In the library column, there are books and magazines addressing different tastes, and a wide variety of spices in the spice column. The table, chairs, and armchairs column concept for each column reflect (Duran and Babur, 2011: 92).

The Blind Restaurant at the Adam \& Eve Hotel, the world's leading design hotel, which has adopted an innovative approach, serves its guests in a completely dark room with excellent technical and safety conditions for dinner.

Guests who make reservations and choose their menus before arriving at this 16-seat restaurant are beginning to experience dining in the dark after being guided by experienced staff (www.adamevehotels.com). An example of a different innovation applied by the hotel companies to music is the music concept offered 
to the guests of Adam \& Eve hotel in Antalya Belek. Guests have the opportunity to listen to very different styles of music in every room they go to in the hotel. Thus, a wide range of music alternatives is offered to guests with different musical cultures (Duran and Babur, 2011: 90).

\section{RESULTS AND DISCUSSION}

Experience can be considered as pleasant memory and emotions that businesses make for their customers. These pleasant memories and feelings attract the customers to operate; affect them emotionally and even shape their intention to become customers again. Experiential marketing, a customer-centric approach, covers all activities that can reach all the senses of the customer, which can affect them emotionally and cognitively, and drive them to a purchase-like action.

The tourism event involves a process based on experience. Along with the increase in the quality of life, aesthetic value, that is part of the experiential value in touristic consumption, appears in the forefront. In the postmodern world, tourism products should be enriched in the context of fantasy, emotion, and entertainment. Environments where tourism products are used should be considered as a theater scene, whereas tourists should be regarded as actors. Businesses offer consumer satisfaction as the tourism product that target markets have previously design for consumer needs.

Nowadays, tourism industry is focused on establishing and managing special experiences for consumers. On the other hand, tourism industry is struggling not only to present the functional dimension of the product to consumers but also to enrich it with the experiential dimension of the tourism product. In this context, businesses are conceiving a competitive advantage, focusing on the fields of "Dream Society", "Entertainment Economy", "Attention Economy" and "Experience Economy" that the era brings with time.

\section{REFERENCES}

BABACAN, M. ve ONAT F.; (2002), "Postmodern Pazarlama Perspektifi, Ege Akademik Bakış,2(1), 11-19.

Berry LL, Wall EA, Carbone LP (2006) Services clues and customer assessment of the service experience: lessons from marketing. Acad Manag Perspect 20(3):43-57

DURNA, U. Ve BABÜR, S; (2011), Otel İşletmelerinde Yenilik Uygulamaları”, Uluslararası Alanya İşletme Fakültesi Dergisi, Cilt 3, sayı 1. 
ERIN, Y.Y., KENNY, C.W.; (2008). "Relatıonships Among Expertentıal Marketıng, Expertentıal Value, And Customer Satısfactıon," Journal of Hospitality \& Tourism Research, Vol. 32, No. 3, 387-410.90

Gilmore J, Pine J, (2002). “The experience is the marketing”. Strategic horizon LLP, BrownHerron Publishing, ISBN: B00006JMDC, S.4

GÜNAY, N.G., (2008). "Deneyimsel Pazarlama: Süpermarketler Nasll Deneyim Yaratabilirler?”, Muhan Soysal Işsletmecilik Konferansı Bildiri Kitapçı̆̆ı, ss. 181-192, 3-6 Eylül, Kıbrıs: ODTÜ Kuzey Kıbrıs Kampüsü.

Hosseini, Robabeh Sadat, Artinah Zainal, and Norzuwana Sumarjan. (2015). "The Effects of Service Performance of Hotel Customers on Quality of Experience and Brand Loyalty in Iran." Procedia-Social and Behavioral Sciences 201: 156-64.

KABADAYI, TÜMER, E., KOÇAKALAN, A.; (2014), "Deneyimsel Pazarlama: Pazarlama'daki Artan Önemi', İşletme Araştırma Dergisi

http://www.isarder.org/isardercom/2014vol6issue1/vol.6_issue.1_article013.full.text.pdf

KAZANÇOĞLU, İ., VENTURA, K., TATLIDİL, R.; (2011), “Deneyimsel Pazarlama Yaklaşımı ile Özel Alışveriş Klüplerine Yönelik Mobil Uygulamalar”), 16. Ulusal Pazarlama Kongresi, 22-25 Kasim.

http://www.pazarlama.org.tr/dosyalar/22-02-2014-11-04-37.pdf\#page=235

Khan, M., Garg, R. J. \& Rahman, J. (2015). Customer service experience in Hotel operations: An empirical Analysis. Procedia-Social and Behavioural Sciences, 189, 266-274.

MURAT, N.; (2013) “Deneyimsel Pazarlamanın 3 Kritik Yararı”. http://www.pazarlamasyon.com/2013/04/deneyimsel-pazarlamanin-3-kritik-yarari/

ODABAŞI, Y.; (2004). “Müşteri İlişsilerinden Müşteri Deneyimine; Starbucks Falda Bakar $m \imath$ ”, Sabah Business, 22, 12-13, http://yavuzodabasi.wordpress.com.

ORAL, S., ÇELIKK, A. ; (2013), “Türkiye'yi Ziyaret Een Turistlerin Estetik Deneyimleri Üzerine Bir Arştırma”, İşletme Araştırmaları Dergisi, Cilt 5, Sayı 4.

http://www.isarder.org/isardercom/2013vol5issue4/vol.5_issue.4_article11_full_text.pdf

ÖZGÖREN, F. ; (2013), “Deneyimsel Markalama”, Sosyal Bilimler Dergisi, Sayı 3, Bahar.

http://www.arastirmax.com/system/files/dergiler/128353/makaleler/3/1/arastrmx_128353_3_ pp_1-19.pdf

PAPATYA, N., PAPATYA, G., ve Güzel, Ö.; (2013), “Deneyimsel Değer Yaklaşımında Kritik Değer Sürücüleri: Muğla Bölgesinde Faaliyet Gösteren Dört ve Beş Yıldızlı Konaklama İşletmelerinde Bir Araştırma”, Uluslarası Yönetim İktisat ve İşletme Dergisi, Cilt 9, Say1 19.

http://www.ijmeb.org/index.php/zkesbe/article/view/376

PAPATYA, N., PAPATYA, G. VE HAMŞİOĞLU, A. B;(2011a), "Sürdürülebilir çevre ve 
kaynak tabanlı turizm: Eğirdir bölgesine ilişkin bir değerlendirme eleștirellyapıcı bir yaklaşım", 1-4 Aralık I. Uluslararası IV. Ulusal Eğirdir Turizm Sempozyumu Bildiriler Kitab1, 221-236.

PAPATYA, N., PAPATYA G., \& ÖZDEMIR, Ş. (2011b);. "Deneyimsel pazarlama açısından Isparta ili ekolojik köy turizm potansiyelinin etkinleştirilmesine yönelik bir değerlendirme”, 1-4 Aralık I. Uluslararası IV. Ulusal Eğirdir Turizm Sempozyumu Bildiriler Kitabı, 459-466.

POULSSON, S.H.G., KALE, S.H.;(2004)., "The Experience Economy and Commercial Experiences. The Marketing Review”, 4(3),267-277.

Schmitt, Bernd, H. (1999), Experiential Marketing: How to Get Customers to Sense, Feel, Think, Act, and Relate to Your Company and Brand, New York: Simon \& Schuster.

SALTIK, ARIKAN, I.; (2011), “Turizm Sektöründe Deneyimsel Pazarlama ve Tüketici Tercihleri Üzerine Etkisi”, Muğla Üniversitesi Sosyal Bilimler Enstitüsü. Anatolia: Turizm Araştırmaları Dergisi, Cilt 22, Sayı 2.

Slåtten T, Krogh Ch, Connolley S, (2011) "Make it memorable: customer experiences in winter amusement parks", International Journal of Culture, Tourism and Hospitality Research, Vol. 5 Issue: 1, pp.80-91, https://doi.org/10.1108/17506181111111780

SUNDBO, J., DARMER, P.; (2008), “Creating Experiences in the Experience Economy”, Edward Elgar Publishing, Bodmin, Cornwall.

SONGUR, A., ŞENOL, H., VE TÜFEKÇİ, Ö, K., (2012). "Deneyimsel Pazarlama Yoluyla Üzümün Pazar Payını Artırma: Sarıgöl Değerlemesi”.

Thomson N.H., (2010). "Virtual Experiential Marketing At Marriott International, Inc.: An Examination Of Effects On Consumer Purchase Intentions". Cameron School of Business. University of North Carolina Wilmington

http://www.sarigolsempozyumu.com/index.php\%20?option=com_\%20docman\&task=doc dow

UYGUR, S., DOĞAN, S. ; (2013), “Deneyimsel Pazarlama'nın Müşteri Memnuniyeti Üzerine Etkisi: Restorantlar Üzerine Bir Araştırma”, Dumlupınar Üniversitesi Sosyal Bilimlar Dergisi, Sayı 37, Temmuz.

http://www.arastirmax.com/system/files/dergiler/249/makaleler/37/arastrmx_249_pp_1. pdf

YU, H., KO, H.T. ;(2012), “Integrating Kano model with strategic experiential modules in developing ICT-enabled services: An empirical study. Management Decision," 50(1),720.

\section{Web Pages:}

http://www.adamevehotels.com/luxury_hotel/parties/tr/musicConcept.aeh http://www.gezirezervasyonu.com/ucak-kabini-odali-havaalani-oteli-yotel/ 
http://www.gezikolik.com/tr/Gezelim_Gorelim/Genel_Bilgiler/Italya/Dunyanin En_\%E2\%80\%9CHip\%E2\%80\%9D_Otelleri_/e_4022.aspx

http://www.meetschmitt.com/Media/Turkish/Pazarlamanin\%20en\%20Yeni\%20Gozdesi\%20 1-4.pdf

http://prezi.com/ft00-4mox54y/1-deneyimsel-pazarlama-kavrami/

http://www.ulviyaman.com/blog/bilgi-belge/deneyimsel-pazarlama/ 